D. F. Zandstra

A. J. Petros

L. Silvestri

M. A. de la Cal

N. Taylor

V. Damjanovic

H. K. F. van Saene

\section{Selective decontamination of the digestive tract: selectivity is not required}

Accepted: 21 April 2010

Published online: 7 July 2010

(C) The Author(s) 2010. This article is published with open access at

Springerlink.com

A reply to this letter can be found at: doi:10.1007/s00134-010-1947-9.

Dear Editor,

We read Benus and colleagues' article entitled 'Impact of digestive and oropharyngeal decontamination on the intestinal microbrota in ICU patients' [1]. Benus tested the hypothesis that selective decontamination of the digestive tract (SDD) may achieve its claimed benefits by leaving the anaerobic intestinal microbiota unaffected, which indicates a misunderstanding of SDD [2]. SDD was designed based on the observation that critical illness changes flora. Critical illness promotes a shift from normal ( $S$. pneumoniae in the throat and E. coli in the gut) towards abnormal carriage (aerobic Gramnegative bacilli and methicillinresistant Staphylococcus aureus) and overgrowth of both. Parenteral cefotaxime controls overgrowth of 'normal' flora, whereas abnormal flora is controlled by enteral polymyxin/tobramycin. There are 60 randomised controlled trials (RCT) and 10 meta-analyses confirming that SDD reduces pneumonia ( $72 \%$ ), septicaemia $(37 \%)$ and mortality (29\%) without resistance emerging.

Benus's article focuses on 'selectivity'. Anaerobes rarely cause infections; instead, the indigenous anaerobic flora contributes to physiology and control of abnormal carriage, i.e. it promotes colonisation resistance (CR) [3]. Antimicrobials suppressing anaerobes are 'nonselective', those leaving them virtually intact are 'selective'.

Using fluorescent in situ hybridization, Benus demonstrates that SDD impacts the indigenous flora, particularly Faecalibacterium prausnitzii, an anaerobic Gram-negative bacillus significantly reduced by high faecal tobramycin levels. They hypothesize that $F$. prausnitzii plays a role in maintaining $\mathrm{CR}$, therefore SDD cannot be beneficial by leaving colonic microbiota unaffected. Interestingly, the faecal samples studied by Benus were collected from ICU patients enrolled in a recent RCT showing efficacy and safety of SDD [1].

The only conclusion is that SDD is effective and safe although not selective, as described by Vollaard et al. [3]. Donskey [4] wrote that SDD has tremendous potential although it is not truly selective.

Six healthy volunteers were challenged with cefotaxime-resistant Enterobacter cloacae after intravenous administration of cefotaxime [3]. All became carriers, five experienced overgrowth, and all cleared the strain during pre-treatment without cefotaxime. Parenteral cefotaxime was chosen for SDD [2] as it has been shown to control overgrowth of normal flora through its high salivary and biliary concentrations. These levels are also bactericidal against Clostridium species, Gram-positive bacilli amongst the indigenous anaerobes, and are thought to contribute to CR [5].

Benus assessed the impact of SDD on CR in 17 ICU patients and reports a significant reduction in $F$. prausnitzii, which is hypothesized to play a role in maintaining $\mathrm{CR}$, in contrast to Wensinck who showed that CR is based on anaerobic Grampositive Clostridium species. Hence, Benus concludes that SDD is not selective.

Benus fails to acknowledge Vollaard's and Donskey's work, although both are relevant to the assertion that SDD is a contradiction in terms, i.e., effective decontamination or eradication of gut overgrowth whilst maintaining complete selectivity does not make sense. However, the originators of SDD have always been aware of this contradiction in terms [2] preferring effectivity over selectivity, if negative consequences of non-selectivity are neutralised by enteral antimicrobials (polymyxin/ tobramycin/amphotericin B).

In conclusion, SDD exerts benefits via antimicrobial concentrations effective against overgrowth of normal and abnormal flora rather than by sparing the CR flora. The clinical impact of $F$. prausnitzii reduction in the critically ill is unclear.

Open Access This article is distributed under the terms of the Creative Commons Attribution Noncommercial License which permits any noncommercial use, distribution, and reproduction in any medium, provided the original author(s) and source are credited.

\section{References}

1. Benus RF, Harmsen HJ, Welling GW, Spanjersberg R, Zijlstra JG, Degener JE, van der Werf TS (2010) Impact of digestive and oropharyngeal decontamination on the intestinal microbiota in ICU patients. Intensive Care Med. doi: 10.1007/s00134-010-1826-4

2. van Saene HKF, Stoutenbeek SP (1987) Selective decontamination. J Antimicrob Chemother 20:462-465 
3. Vollaard EJ, Clasener HA, Janssen AJ, Wynne HJ (1990) Influence of cefotaxime on microbial colonization resistance in healthy volunteers. J Antimicrob Chemother 26:117-123

4. Donskey CJ (2004) The role of the intestinal tract as a reservoir and source for transmission of nosocomial pathogens. CID 39:219-226

5. Wensinck F, Ruseler-van Embden JGH (1971) The intestinal flora of colonization resistant mice. J Hyg (London) 69:413-421
D. F. Zandstra

Department of Intensive Care, OLVG, 1st Oosterpark Str 279, 1090 HM Amsterdam, The Netherlands

\section{A. J. Petros}

Paediatric and Neonatal Intensive Care Unit, Great Ormond Street Hospital for Children, Great Ormond Street, London WC1N 3JH, UK

L. Silvestri

Department of Emergency, Unit of Anesthesia and Intensive Care, Presidio Ospedaliero, Via Fatebenefratelli 34, 34170 Gorizia, Italy
M. A. de la Cal

Unidad de Cuidados Intensivos y Grandes Quemados, Hospital Universitario de

Getafe, Getafe, Madrid, Spain

N. Taylor $(\bowtie) \cdot$ V. Damjanovic ·

H. K. F. van Saene

School of Clinical Sciences,

University of Liverpool, Duncan Building,

Daulby Street, Liverpool L69 3GA, UK e-mail: nia.taylor@liv.ac.uk

Tel.: +44-151-7064923

Fax: +44-151-7065803 